\section{Um romance etnográfico}

Philippe DESCOLA. As lanças do crepúsculo: relações Jivaro na Alta Amazônia. São Paulo, CosacNaify, 2006. 520 páginas.

\section{Clarice Cohn}

Um etnólogo em campo. É esse o mote do presente livro: um relato de pesquisa etnográfica, dos dois anos que Philippe Descola e sua esposa, Anne Christine Taylor, também antropóloga, passaram entre os Achuar do Equador. Mas ele resulta em muito mais do que isso. Para além de um feliz exercício de apresentação para um público não especializado do trabalho do antropólogo e dos resultados que dele advêm, é uma combinação de romance e etnografia. De certo ponto de vista, a organização do livro em três partes, que acompanha as relações jivaro com a natureza, em sociedade e com o sobrenatural, remete a uma organização clássica dos dados que as monografias por tanto tempo deram às sociedades e às humanidades de que tratam - economia, política, religião. Mas isso é só aparente, e vem a servir a uma subversão dessa ordem. Descola subverte, com os Achuar, a ordenação de mundo que está por trás dessa organização textual - as relações com a natureza, afinal, não são com a natureza tal como a concebemos, as relações sociais revelam-se muito mais complexas e bem mais ricas do que certos quadros descritivos levariam a crer, o sobrenatural invade o cotidiano e o mundo vivido. As fronteiras e as definições são borradas, mexidas, torneadas aos moldes achuar.

Só por isso o livro já valeria - pela demonstração, que deve fazer toda boa antropologia, da sofisticação e da beleza dos mundos vividos, inventados, concebidos pelas tantas outras parcelas da humanidade que nos rodeiam. E por fazê-lo incorporando os ensinamentos da etnologia contemporânea, de que Descola é um expoente. Afinal, as diferenças culturais são tão grandes que o esforço intelectual, o exercício cognitivo para dar conta delas são também imensos, e os desafios de expressá-los correspondentemente grandes. Descola o tem realizado em diversos meios - livros de antropologia, artigos publicados em revistas especializadas, aulas e conferências. Neste volume, o desafio que enfrenta é outro: o de escrever para o grande público. E, assim, subverte a própria escrita etnográfica.

Vários livros de antropologia ganharam um alcance muito mais amplo que o público especializado. A antropóloga norte-americana Margaret Mead costumava explicar a penetração de suas análises dizendo que escrevia em inglês, e não em antropologuês. No Brasil, além dos diversos relatos de viajantes e exploradores que cruzaram o país, há também bons relatos de antropólogos, como o ótimo $O$ selvagem e o inocente, em que David Maybury-Lewis conta as aventuras e desventuras que ele e sua esposa Pia - e depois também o filho - passaram no período de pesquisa entre os Xerente e os Xavante do Brasil Central, as já clássicas Crônicas dos indios Guaiaky, em que o encontro da filosofia política e da antropologia, que tão bem faz Pierre Clastres, ganha o cenário do encontro do antropólogo com aqueles que inspiram suas reflexões, ou o belíssimo Diários indios, reunião das cartas que Darcy Ribeiro escreveu para sua então esposa, Berta Ribeiro, em que relata suas experiências, impressões e reflexões durante sua pesquisa com os Urubu-Kaapor do Maranhão. Este livro de Descola insere-se, ele mesmo, em uma coleção, a "Terre Humaine", que vem sendo editada pela prestigiosa editora Plon há meio século, tendo sido precedido - e sucedido, a edição original, em francês, é de $1993^{1}$ - por diversas outras experiências desse tipo.

O famoso Tristes trópicos, de Lévi-Strauss, segundo volume dessa mesma coleção francesa, se inicia com a também famosa indecisão do autor sobre a pertinência de escrever nesse "gênero de narrativa [que] goza de uma aceitação que para mim continua inexplicável", a dos relatos de viagens e de exploradores, a narrativa sobre "tantos esforços e despesas inúteis [que se fazem necessários] para se atingir o objeto de nossos estudos [e que] não conferem qualquer valor àquilo que pode ser considerado o aspecto negativo da nossa profissão, [já que] as verdades que vamos procurar tão longe só têm valor quando libertadas dessa ganga". O antropólogo não é um viajante - seu relato de viagem é um relato de pesquisa. Mas então - é o que parece se perguntar Lévi-Strauss - para que relatá-la, e não se limitar a escrever artigos, monografias, análises antropológicas, que é a vocação do etnólogo, o objetivo confesso de suas viagens, e a vocação da (parafraseando a expressão do próprio Descola) escritura etnológica?

Gostaria de apontar duas razões para se escrever sobre a experiência de campo, que são, am- 
bas, reveladas pela leitura deste livro: uma é que etnografias podem render bons romances; outra é que esses romances etnográficos podem ser bons meios de extrapolar a academia e atingir o grande público, justamente o público sedento pelos relatos de viagem de que falava Lévi-Strauss e que pode assim ter acesso também à antropologia em linguagem vernacular. De fato, Descola tem plena consciência de ambas as questões - em um post-scriptum, comenta essas escrituras da etnografia, em comparação à maior liberdade da narrativa que apresenta ao leitor, assim como revela como uma das motivações para escrever o livro a responsabilidade do etnólogo tanto para com as pessoas com que pesquisou como para com aquelas que financiaram suas pesquisas e têm direito ao acesso de seus resultados. Nesse movimento, os Achuar que se alfabetizam podem vir a ter acesso ao que os antropólogos produzem sobre eles, e a divulgação daquilo que se pode aprender como antropólogo sobre uma parcela da humanidade contribui para despertar "uma humanidade demasiado impaciente para amar a si mesma sob um novo rosto".

Se $A$ s lancas do crepúsculo pode ser remetido a uma tradição dos relatos etnográficos, resulta, ainda assim, extremamente original. Nessa versão antropológica dos relatos de viagens, Descola faz mais: constrói um verdadeiro romance - ou um livro de contos -, em que personagens, histórias, dramas, encontros e desencontros se entrelaçam e se desenrolam. Ao longo do texto, vamos sendo apresentados a inúmeros personagens muito bem construídos, tal qual num bom romance, tal qual executa um bom escritor, em suas personalidades, particularidades, afeições, idiossincrasias... Vivem situações que os colocam em face de escolhas, decisões, reflexões sobre a vida e suas relações. Empreendem grandes viagens, em meio à dúvida sobre como serão recebidos na próxima parada. Planejam trocas, buscam suas indenizações a partir da lógica da vendeta. Aliam-se aos antropólogos, inserem-nos a suas redes de trocas. Casam-se, separam-se, apaixonamse, são felizes ou infelizes no amor. Buscam desvendar o mistério do assassinato, cuja trama é discutida por todas as terras achuar. Ou simplesmente vivem suas vidas, catam piolho da cabeça de uma criança, tomam cerveja de mandioca, dormem, acordam. São eles os companheiros do casal de antropólogos em suas aventuras, e com eles vamos aprendendo a conhecer e entender os Achuar.
No decorrer da narrativa, temas clássicos da antropologia - como a divisão do trabalho, o trabalho na roça, a caça, os casamentos e os cálculos de aliança, os rituais, as curas xamânicas, entre outros vão sendo desenvolvidos e explorados de modo pouco usual se comparado às monografias acadêmicas. Deparamo-nos também com temas bem menos explorados nesse tipo de monografia - o amor, os modos de amar, os segredos íntimos da vida etc. Aqui essas questões são animadas pelo recurso narrativo, que dá vida a personagens cujos nomes e rostos vamos conhecendo e compreendendo.

A passagem dedicada à interpretação dos sonhos condensa muito do que há de melhor no livro, apresentando a inserção do antropólogo em campo, a maneira como constrói seu conhecimento em diálogo com os nativos e com a antropologia, o encantamento da descoberta, de modo a que temas caros aos etnólogos ganhem não só espaço, mas também tratamento literário, que lhes confere vida, sem com isso prejudicar a profundidade da análise antropológica ou as referências analíticas e os posicionamentos no campo do debate antropológico.

$\mathrm{O}$ relato de um sonho que pressagia boa caça é apresentado por meio do diálogo em forma de transcrição, momento em que se expõem as classificações achuar dos sonhos - de presságio, de mau agouro - a partir do sonhador, do conteúdo, do que é sonhado. A interpretação do antropólogo sobre o que os Achuar pensam dos sonhos, como os classificam, como os interpretam, é acompanhada por comentários e interpretações dos próprios achuar. Revelam-se, assim, a beleza da exegese nativa e a operação analítica do antropólogo para entendê-la em uma construção narrativa excepcional, pela qual o "sonho verdadeiro" - aquele que é um diálogo de almas e cujo significado, ao contrário dos outros tipos de sonhos, deve ser buscado e se revela por meio de metáforas - é apresentado, ele mesmo, em forma de diálogo. Mais ainda, as interpretações nativas vão se mostrando cada vez mais próximas da análise estrutural dos mitos, referência teórica e metodológica do antropólogo, que compartilha com o leitor seu prazer em vê-lo acontecendo, especialmente quando a exegese nativa do sonho ganha correspondência exata a uma análise estrutural anterior: "explicitada em um presságio achuar, a relação estrutural isolada pela análise de um material mitológico estranho à cultura jivaro adquiria a densidade incontestável do vivenciado; 
eu me via então naquela situação, bem conhecida dos físicos, em que um experimentador 'descobre' a existência empírica de um fenômeno que a teoria já predissera” (p. 143). Em meio a esses diálogos múltiplos que se interpenetram tanto no texto como na experiência etnológica - o das almas que possibilitam o sonho, o do etnólogo com o nativo que sonha, o da interpretação do sonho feita pelos nativos e pelo próprio antropólogo e, enfim, o diálogo do etnólogo em campo com a antropologia e a teoria antropológica -, Descola conclui: "longe de prejudicar a pureza do olhar, certa erudição acaba dando ao etnógrafo uma oportunidade para essas pequenas demonstrações do real que animam o trabalho de campo com o prazer da descoberta".

Essa passagem revela ainda outro valor que o relato adquire em uma pesquisa de campo: ser um meio, raríssimo, pelo qual os etnólogos podem partilhar suas experiências. Todo etnólogo que chega a campo deve ter a mesma impressão de ter que inventar a roda. Sem técnicas precisas de mensuração, aferição, verificação ou mesmo coleta de dados, deve contar com sua intuição, sua capacidade de se relacionar, seus talentos, muitos deles jamais pressentidos, e se vê com suas limitações, algumas já sabidas, mas um bom número delas também por ele desconhecidas. Deve lidar simultaneamente com suas expectativas, com o risco constante de vê-las frustradas, os temores de seus maiores pesadelos, e o entusiasmo das descobertas imprevistas. Livros como este oferecem ao etnólogo experimentado momentos de reconhecimento e cumplicidade, situações em que a graça que advém da experiência compartilhada rende boas risadas. Para o etnólogo neófito, trata-se da melhor demonstração do conjunto de acasos, planos frustrados, mal-entendidos, mas também amizade, companheirismo e momentos de inspiração que compõem a pesquisa e nos leva a entender gradativamente este novo lugar. É a mais profícua demonstração daquilo que os partidários da pesquisa de campo já sabem, que está anunciado na clássica introdução metodológica de Malinowski, a qual também já partia da identificação quase machadiana criada pelo texto - imaginese o leitor em uma praia de uma ilha distante, vendo o barco, que é seu único elo com o resto do mundo, se afastar...-, e que foi também, contanos Descola, o grande ensinamento metodológico dado por seu orientador, Claude Lévi-Strauss, antes de sua partida: "deixe-se levar pelo campo".
Mas o equilíbrio entre uma monografia acadêmica e uma narrativa romanceada é difícil, e às vezes os vícios de linguagem antropológica superam a narrativa ficcional. Bem feitas as contas, as descrições e as análises etnológicas são mais longas do que o compartilhamento da experiência de campo. O papel do etnólogo na construção do conhecimento, que torna o relato tão rico, tem peso no começo da narrativa, mas quase desaparece no decorrer do texto. A reflexão sobre seu ofício, vocação e posição está quase que circunscrita ao início da história, quando a construção ainda está sendo forjada e, por isso mesmo, repleta de questionamentos. Adiante, o antropólogo, suas dúvidas e o prazer que sente nas descobertas vão cedendo espaço à descrição propriamente dita. $\mathrm{O}$ romance perde espaço para a etnografia, o livro vai ganhando ritmo de uma monografia.

A graça se perde um pouco, e ao menos o etnólogo experimentado e conhecedor do trabalho de Descola perde de vista a particularidade, de resto tão envolvente, do livro. Mas, quando se percebe que o desfecho traz à tona com renovada força e reflexividade a posição do etnólogo, aquilo que antes parecia uma perda ganha, pela negativa, um poderoso e imprevisto estatuto reflexivo. Entende-se então que, no meio do caminho, a inserção do etnólogo em campo faz esvanecer seus incômodos e suas empolgações à medida que o trabalho vai sendo elaborado. O fim da experiência de campo, marcado pela sensação de que não há mais nada de novo a conhecer, acaba por revelar uma derradeira e inesperada descoberta: a reflexão sobre o ofício, a vocação e as desventuras do antropólogo, quando suas dúvidas e seu prazer da descoberta reaparecem fechando de maneira impressionante a narrativa. Sobretudo após um percurso árduo, em que o leitor, cúmplice desse laborar em campo, percorreu cerca de uma centena de páginas em que a experiência da pesquisa cede gradativamente espaço a seus resultados. Uma linda alegoria desse momento em que se percebe o trabalho completo, único e ansiado ao longo de todo o percurso de pesquisa.

Descola afirma que a antropologia não é uma aventura, ou que nela a aventura não é um fim em si, e que o antropólogo recorrentemente nasce da curiosidade do leitor e não da inquietação do aventureiro. Evoca Leach, que dizia serem os antropólogos romancistas frustrados, para falar de uma particular vocação literária que esse leitor feito aven- 
tureiro conquista na etnologia, não tendo o talento dos poetas e dos romancistas: "a observação das culturas exóticas torna-se então uma forma de substituição: permite ao etnólogo entrar no mundo da utopia sem submeter-se aos caprichos da inspiração" (p. 45). Para o autor, As lanças do crepúsculo é um modo de escapar das teias rigorosas do gênero narrativo canônico da etnologia. Ele tem consciência disso, e nos diz que a distância temporal que afasta a experiência de campo da redação faz com que o livro seja inevitavelmente ficcional, ainda que tenha tido por base acontecimentos vividos e observados, ainda que seus personagens tenham sido construídos a partir de pessoas conhecidas, por quem ele nutrira simpatias ou antipatias, ou, por fim, que tenha usado como recurso os cadernos de campo.

Relato etnográfico, romance, monografia, ficção e biografia - a obra resulta uma multiplicidade de gêneros. Trata-se de um poderoso meio de acesso ao trabalho do etnólogo. É também lugar de uma reflexividade de fazer inveja - nele se fala das relações com os índios, das dificuldades com os informantes, das dificuldades mesmo de concebêlos como informantes, do lugar do antropólogo, do estatuto de seu conhecimento tão laboriosamente construído e assim por diante. Revela um percurso para que se conheça as relações jivaro, incluindo-se aquela com seus antropólogos. Antropologia de peso, As lanças do crepúsculo é etnopoesia, quase uma metaliteratura, em que se traduz, comenta, interpreta encantamentos, poesias, versos apaixonados. Enfim, um belo romance etnográfico, de que resenha alguma fará jus. Resta convidar o leitor a, como disse uma vez Vinicius de Moraes, "tomar do livro, deitar na rede, acarinhar o gato que vem deitar em sua barriga e se deleitar".

\section{Nota}

1 Incidentalmente, enquanto o livro de Descola ganha uma tradução e edição brasileira, o livro de Darcy Ribeiro ganha seu espaço na coleção "Terre Humaine".

CLARICE COHN é antropóloga e professora do Departamento de Ciências Sociais e do Programa de Pós-Graduação em Antropologia Social da Universidade Federal de São Carlos (UFSCar).

E-mail: clacohn@gmail.com.

\section{Repensar os estudos: os impactos do 11 de Setembro no pensamento liberal}

Francis FUKUYAMA. Construção de Estados, governo e organização no século XXI. Tradução de Nivaldo Montigelli Jr. Rio de Janeiro, Rocco, 2004. 168 páginas.

\section{Reginaldo Mattar Nasser}

Pode-se dizer que no plano intelectual a era do pós-Guerra-Fria teve início com a profecia de pensadores como Fukuyama, de que a queda do comunismo e o triunfo das democracias liberais eram os sinais do começo da "etapa final”, em que não haveria mais lugar para grandes lutas ideológicas. Nesse sentido, poder-se-ia afirmar que a história havia terminado. $\mathrm{O}$ fim da História não significaria o alcance de um sistema perfeito, mas a eliminação de quaisquer alternativas melhores para ele. ${ }^{1}$

Porém, doze anos depois o mesmo Fukuyama que saudou os anos de liberalização econômica, cujo objetivo dominante foi reduzir o campo de abrangência das atividades do Estado, constatava que as políticas de privatização, liberalização e desregulamentação, motivadas pelo consenso de Washington e pelas instituições financeiras internacionais, como o Fundo Monetário internacional, tiveram um efeito altamente perverso. Estava na hora de conclamar a volta do Estado (Fukuyama, 2004).

O problema, que hoje se tornou dramático, é a constatação de que o projeto implementado com êxito em países como Estados Unidos e Inglaterra não poderia ter a mesma eficácia em outros países. O consenso de Washington, observa Fukuyama, "era uma lista perfeitamente sensata de medidas de política econômica" (p. 32) concebidas para diminuir o escopo das funções do Estado por meio de tarifas de proteção reduzidas, privatizações e desregulamentações. Mas no processo de redução do escopo do Estado, muitos países tiveram que reduzir a força do Estado ou gerar demandas por novos tipos de capacidade do Estado, que eram fracas ou inexistentes.

De acordo com o autor, "as crises financeiras enfrentadas pela Tailândia e pela Coréia do Sul estavam diretamente ligadas à liberalização prematura da conta de capital na ausência de instituições 